\title{
CROSS-COUNTRY EVIDENCE ON THE DEMAND FOR MONEY*
}

\section{INTRODUCTION}

The relationship between the demand for money and its determinants is an underlying building block for most theories of macroeconomie behavior. Researchers have long been preoccupied on the subject matter, because the demand for money is considered a crucial component in conducting monetary policy. Furthermore, stability in the demand for real balances has been viewed as a requirement for policy makers to utilize monetary aggregates as strategic mechanisms. Typically, researchers in this field model a real monetary aggregate as a function of both an opportunity cost and a scale variable. The objective is then to empirically test long-run theories of the demand for money, such as the classical quantity theory demand for money or the Baumol (1952) and Tobin (1956) transactions theory.

One of the major contributors of the empirical research on money demand has been the recent key advances in time-series econometrics. In particular, the contemporary time-series literature has adopted the methodology of modeling trends and investigating cointegrating properties of the aggregate money demand function through error correction models see, for example, Hoffman and Rasche (1996). The error correction model representation captures the long-run equilibrium relationship between money and its determinants while embedding the short-run dynamics defined by the data generating process. As such, these innovative techniques have inspired researchers to revisit previously built empirical models and their findings.

However, past estimation has primarily been confined to industrialized countries, especially the United States, the United Kingdom, and more recently Canada — see Goldfeld and Sichel (1990), Sriram (1999), and Serletis (2001) for surveys on past theoretical and empirical money demand studies. Thus, it has been difficult

* Serletis gratefully acknowledges financial support from the Social Sciences and Humanities Research Council of Canada (SSHRCC). 
to draw broad conclusions about long-run money demand based on only a handful of countries, which can be argued to be similar in nature. Sriram (1999) provides a comprehensive summary of money demand studies involving cointegration and error-correction models for selected industrial and developing countries. Most of the findings suggest that the conventional variables are integrated of order one [or I(1) in the terminology of Engle and Granger (1987)], but that the cointegrating relationship between these variables can be sensitive to the monetary aggregate, interest rate, or scale variable chosen.

Others such as Kenny (1991), Mulligan and Sala-i-Martin (1992), Fujiki and Mulligan (1996), and more recently Fischer (2005), have opted for an alternative modeling approach to the error correction model framework. The first three studies estimate money demand cross-sectionally. This approach is appealing given that the elasticity estimates derived from the time-series approach seem to be sensitive to the choice of sample period, functional form, number of lags, and the univariate and multivariate time series properties of the underlying variables. For these reasons (among others), Friedman and Kuttner (1992, p. 490) argue that time-series data does not uncover a "close or reliable relationship between money and nonfinancial economic activity."

The cross-section approach also allows researchers to utilize additional conditional variables, which may not be available as a time-series. For example, in his cross-country study, Kenny (1991) conditions on inflation, the fraction of the population who are elderly, education, agriculture, population density, and then he includes dummy variables for dictatorships and the 1970's. Alternatively, the Mulligan and Sala-i-Martin (1992) cross-state American study includes state specific variables for population, population density, agricultural sector's share of income, and regional dummies. The findings and conclusions drawn from both studies indicate that supplementary variables can enhance standard inferences regarding money demand.

More recently, Fischer (2005) attempts to reconcile parameter biases in the conventional money demand estimates by conditioning on heterogeneous levels of financial sophistication in his cross-regional panel analysis of Switzerland. In particular, Fischer considers four proxies in his attempt to measure financial sophistication. The first, is population density of a canton, the second is impact of financial centers, the third is the economic structure of a canton, and the last proxy measure of financial sophistication considers the number of automated teller machines (ATMs) in a canton - a canton is the Swiss definition for what is known as a province or a state 
elsewhere. However, his results show that the estimated income elasticity is consistent with the Baumol-Tobin transactions theory hypothesis and that proxy measures of financial structure have little or no influence on the stability of Swiss money demand.

In this paper, we have three main objectives. First, we utilize a comprehensive cross-country data set for 48 countries over the 198095 period. The data is comprised of not only conventional money demand variables, but of institutional, financial structure, and financial development measures from Levine (2002). The inclusion of theee additional variables to the conventional money demand function allows us to systematically examine their possible role in the demand for money, at an aggregate multi-country setting. Secondly, we apply an innovative Bayesian approach to cluster the 48 countries into distinct groups. This method of unsupervised classification, based on finite mixture models and statistical attributes, allows us to establish whether heterogeneity in money demand exists between different classes or groups of countries within the data set. It also allows us to investigate whether certain countries can dominate and distort the initial results and conclusions. Lastly, since the number of recent empirical studies relying on geographical diversity is solely limited to regional analysis within Japan, Switzerland, and the United States, we make an initial contribution by extending the current analysis to a global survey.

The organization of the paper is as follows. Section 2 outlines the econometric specification and predictions undertaken for the cross-country data, for both narrow and broad money measures. In the same section we describe the data, as well as the underlying sources of collection and origin, and present the initial crosscountry econometric results. In Section 3, we introduce the Bayesian classification approach, based on finite mixture models, present the results of the Bayesian classification analysis, and explore the economic significance of our clustered regression results. The final section concludes the paper and outlines the implications of our findings.

\section{Cross-country specifications}

Following Levine (2002), we argue that different views regarding money demand can be represented as rival predictions on the parameters of a standard money demand equation and consider the following cross-country money demand regression equations

$$
\begin{aligned}
& m=a^{\prime} X+\varepsilon_{1} \\
& m=a^{\prime} X+b^{\prime} I+\varepsilon_{2}
\end{aligned}
$$




$$
\begin{aligned}
& m=a^{\prime} X+c S+\varepsilon_{3} \\
& m=a^{\prime} X+d F+\varepsilon_{4}
\end{aligned}
$$

where $m$ is the natural logarithm of the real money stock (defined by either a narrow or broad definition) and $X$ represents the standard set of conditioning information that is, the natural logarithm of real GDP and a short term nominal interest rate. As in Levine (2002), $I$ represents a vector of institutional variables which measure macroeconomic stability, openness to international trade, and political stability. $S$ gauges financial structure, with larger values suggesting a more market-based economy and smaller values implying a bankbased economy. $F$ measures the degree of financial development; larger measures of $F$ imply an increased development of securities markets, banks, and non-banks. Such measures can also be interpreted as a proxy for financial services. $\varepsilon i$, with $i=1,2,3,4$, is the corresponding error term for each of the four equations, respectively. $a$, $b$, $c$, and $d$ are estimated coefficients (with bold letters indicating vectors of coefficients). $I, S$, and $F$ are the same variables that Levine (2002) considers as possible growth determinants.

The idea is that countries with greater institutional stability should exhibit less uncertainty and therefore display a reduced demand for money. Specifically, the sign of $b$ will depend on each of the institutional variables under consideration. For example, a higher level of average schooling years over the population implies a stronger knowledge of the mechanics of the economy and the money market, suggesting that the demand for money will be lower as the educational index rises. Large black market premium values indicate that the transaction costs incurred while purchasing goods and services are also large, which in turn requires agents to hold more liquid money. There is also a possible relationship between government expenditure and money demand. Theory asserts that private spending and public spending maybe perfect substitutes or complements see, for example, Barro (1997). If perfect substitutes, then the expenditure on goods and services by the government will reduce expenditure by agents, requiring them to hold less money, ceteris paribus. If complements, then providing additional services will require agents to purchase these services and compel them to retain additional funds, ceteris paribus.

The trade variable attempts to proxy the degree of openness. With enhanced trade comes exposure to different markets, where agents must now consider foreign interest rates and balance of payment issues. As a result, agents will have to divide their monetary holdings 
between domestic and foreign accounts. Higher degrees of openness would suggest that there would be lower demand for domestic money. Measures of civil liberties, revolutions and coups and political assassinations can be thought of as proxies for political stability. With domestic political instability comes capital flight. The theory is that as the future of the financial system becomes dismal, faith in a paper promise declines and faith in other assets such as gold and tangible goods useful for bartering increases. Kenny (1991) considers a similar approach by trying to control for the type of government by including a dummy variable for dictatorships. Our interpretation differs given that the theee political stability variables are not mutually exclusive to countries considered either a dictatorship or democracy. As well, Kenny (1991) emphasizes precautionary motives for his interpretation but neglects speculative motives, which have increasingly dominated financial markets during our sample period.

Bureaucratic efficiency measures the extent of autonomy from political pressures and strength to govern. This is important because it signals a degree of competence within key governmental departments such as finance and the central bank. Given that autonomy and expertise indicate certainty and provide faith in the monetary and political system, the implication is that as the quality of the bureaucracy rises, the demand for money should decline. As with the black market premium measure, corruption can also accordingly be considered a source of raising transaction costs. It is not unreasonable to assume that an increase in corruption would be followed by bribery and possibly influence peddling. Therefore, as we observe an increase in corruption we should also observe an increase in the demand for money.

The addition of financial structure measures allows for investigation into the possible heterogeneity in money demand under diverse financial systems. Specifically, a better understanding of whether money demand is higher or lower in a bank-based or market-based system can be explored. Such analysis and its insights may be useful in formulating monetary policy to remedy a financial crisis or to restructure a command style economy to a more capital driven one, from a policy perspective. Given that, the hypothesis is that under market-based systems firms can easily raise funds in the open market for financing and investment through capital markets, which in turn would broaden loan possibilities. Boot and Thakor (1997) along with Allen and Gale (1999) articulate that competitive capital markets contribute positively in aggregating dispersed information signals and efficiently relay such information 
to investors, with favorable implications for firm level financing see also Levine (2002) for a further explanation and other references on the subject matter. In comparison, under a bank-based system, funds would have to be raised through banks, therefore limiting financing possibilities. Bhide (1993) along with Boot and Thakor (1997) argue that banks act as a coordinated coalition of investors which can monitor firms more efficiently to diminish post lending moral hazard issues and a myopic investor climate. Thus, given the possibility of easily attainable funds under a market based system and the possible impediments under a bank-based system, we should observe the demand for money to be lower in economies where there are market-based characteristics and higher in economies where bankbased characteristics are observed. Hence, we should observe $c<0$.

Financial Services, whether provided by banks or capital markets, can also give broad insight into transaction costs. The idea is that financial arrangements such as contracts, markets, and intermediaries alleviate market imperfections. Levine (1997) stresses that this view curtails the significane of the bank-based and market-based discussion. The argument Levine (2002) makes is that financial arrangements (such as contracts, markets, and intermediaries) highlight prospective investment opportunities, promote corporate responsibility, contribute to risk management, develop liquidity, and reduce savings mobilization. With regards to money demand, the issue is whether such arrangements assist in lowering transaction costs or aid in increasing them. Standard economics textbooks describe financial innovations having a negative effect on the demand for real money balances - see, for example, Barro (1997). However, there is not a definitive hypothesis given that reductions in market imperfections come at a price. Ambiguity arises because the derived benefits from financial services may not outweigh the costs and vice versa. As a result, the data will have to dictate which case is more likely. If the benefits offset the costs, transaction costs decline and the implied sign is $d<0$. Whereas, if the costs overshadow the benefits, transaction costs could rise and the implied sign is $d>0$. Kenny (1991) presents a similar idea by using population density as a surrogate for bank proximity and their corresponding services.

\subsection{The Data}

In order to analyze the possible relationships between real money balances, real GDP, the nominal interest rate, and different institutional, financial structure, and financial development measures, we adopt the common broad cross-country approach, using one 
observation for each variable under consideration, per country, for 48 countries (over the 1980-1995 period). Many of the variables used in this study are derived from census and privately collected data and simply are not available on an annual basis. The countries we consider are the same as those investigated in Levine (2002) and are listed in Table 1. As Levine (2002, p. 405) points out, "one advantage of the broad cross-country approach is that it permits a consistent treatment of financial system structures across countries and thereby facilitates international comparisons." However, we are aware of the potential pitfalls of such analysis, as we cannot exploit the time series dimension of the data. Issues often raised in the money demand literature typically try to address serial correlation of the error term and univariate and multivariate time series properties of the variables involved. There are also possible issues regarding simultaneity between the variables included in the regressions. Our procedure to account for this is explained in the next section.

\section{Table 1 - Countries}

$\begin{array}{ll}\text { Argentina } & \text { Kenya } \\ \text { Australia } & \text { Malaysia } \\ \text { Austria } & \text { Mexico } \\ \text { Belgium } & \text { Netherlands } \\ \text { Brazil } & \text { New Zealand } \\ \text { Canada } & \text { Norway } \\ \text { Chile } & \text { Pakistan } \\ \text { Colombia } & \text { Panama } \\ \text { Cyprus } & \text { Peru } \\ \text { Denmark } & \text { Philippines } \\ \text { Ecuador } & \text { Portugal } \\ \text { Egypt } & \text { South Africa } \\ \text { Finland } & \text { Spain } \\ \text { Frane } & \text { Sri Lanka } \\ \text { Germany } & \text { Sweden } \\ \text { Ghana } & \text { Switzerland } \\ \text { Greece } & \text { Taiwan, China } \\ \text { Honduras } & \text { Thailand } \\ \text { India } & \text { Trinidad and Tobago } \\ \text { Ireland } & \text { Turkey } \\ \text { Israel } & \text { Tunisia } \\ \text { Italy } & \text { United Kingdom } \\ \text { Jamaica } & \text { United States } \\ \text { Japan } & \text { Zimbabwe } \\ \end{array}$

The narrow definition of money chosen is what we shall refer to as M1. The International Monetary Fund (IMF) and standard 
monetary textbooks define such a narrow measure as transferable deposits (demand deposits) and currency outside of banks. The broad definition of money chosen is what we shall refer to as M2. This broad measure is identified as M1 plus quasi money (time, savings, and foreign currency deposits). For the 48 countries included in the study, annual data pertaining to both measures were collected over the 1980-1995 period from the IMF International Financial Statistics (IFS), World Development Indicators (WDI), and various central banks in local currency units (LCU). The data were then converted to United States dollars, by using the U.S. dollar per LCU 1995 average exchange rate, and then averaged to obtain a single data point for each nominal measure of money, for each country.

To analyze the monetary aggregates described above in real terms, we then collected data from the WDI on the consumer price index (CPI) for each country with a base year of 1995. The average was then taken to obtain a single observation for each country. Each of the cross-country monetary aggregates was then deflated by the average consumer price index for each of the 48 countries to obtain a real measure. Although the GDP deflator would have been the ideal price index to use, it was not exploited due to data availability and base year issues. However, for those countries for which we found both, a comparison was made and differences between the two indices were minor if not nil. At any rate, the CPI is the most publicly reported price index. Constant 1995 U.S. dollar GDP data were also collected from the WDI for each country. With regards to short term nominal interest rate data, there were some data availability issues. We could not find a uniformly defined interest rate series for all 48 countries. As a result, data were first collected for countries for which there existed a 90 day treasury bill rate or the local equivalent. Subsequently, data were collected for those countries for which there existed a money market rate. For those countries which neither existed, a deposit rate was collected.

As already noted, the institutional, financial structure, and financial development variables are taken from Levine (2002) - see Levine (2002) for further details regarding the sources of his data collection. We consider nine institutional variables in this study. The first, the logarithm of the initial workforce education, is measured as the average schooling years in the total population over 25 in 1980. The second is the logarithm of one plus the average black market premium and is averaged over the 1980-92 period. The third is the logarithm of government size as a share of GDP and is averaged over the $1980-95$ period. The fourth is the logarithm of 
international trade (real exports and imports) as a share of GDP and is also averaged over the $1980-95$ period. The fifth is an indicator of civil liberties averaged over the 1980's - this indicator is scaled from 1 (most freedom) to 7 (least freedom). The sixth is an index of revolutions and coups averaged over the 1980's. The seventh is political Assassinations - this measures the average number of assassinations per thousand inhabitants, over the 1980's. The eighth is bureaucratic quality, which is scaled from 0 to 6 and averaged over 1982-1995 - high scores indicate autonomy from political pressures, strengths and expertise to govern without drastic changes in policy or interruptions in government services. Lastly, the level of corruption within a given country is indexed through a scale over the 1982-95 period - this index is scaled from 0 (high level of corruption) to 10 (low level of corruption). Levine's inflation variable is left out to avoid any possible simultaneity, given that both measures of money and GDP are in real terms.

Levine constructs and employs a set of five variables to capture comparative differences in financial structure between the 48 countries. The purpose of theee variables is to proxy whether financing in a country is comparatively bank-based or market-based. StructureActivity, Structure-Size, and Structure-Efficiency measure the activity, size, and efficiency of equity markets relative to banks in each country. Levine then forms a comprehensive measure (highest joint R-squared) of the previous three variables called StructureAggregate. Low values of the Activity, Size, Efficiency, and Aggregate measures indicate that an economy is bank-based, whereas high values indicate that an economy is market-based. The fifth variable, Structure-Regulatory, is created to capture the degree of commercial bank restrictions, with smaller values signifying a lower degree of restrictions on commercial banking activities.

In order to observe relative differences in financial development between the 48 countries, Levine also constructed and utilized four measures of financial development. FinanceActivity, Finance-Size, and Finance-Efficiency quantify financial development based on the activity, size, and efficiency of the financial sector within each country. Finance-Aggregate is another comprehensive measure of the three previous variables and is constructed in a similar fashion as the Structure-Aggregate variable. Lower values of these indicators imply underdeveloped financial sectors, whereas higher values imply thriving financial sectors. In his construction of these measures, Levine exploits equity markets as a proxy for capital markets due to data availability in the bond markets. These measures in our view can also be interpreted as a proxy for transaction costs as previously discussed. 


\subsection{Cross-Country Results}

Table 2 presents the initial conventional money demand results using ordinary least squares (OLS) estimation with heteroskedasticityconsistent standard errors. The top panel displays the results for M1 as the dependent variable and the bottom panel those for M2. For both money measures, the estimated income elasticity of the demand for real money balances is highly significant and close to the quantity theory demand for money predictions. Specifically, for both aggregates we tested the null hypothesis that the income elasticity is equal to one, and cannot reject the null at the $5 \%$ level. The estimated interest elasticities of the demand for real balances are negative and both significant at the 5\% level. Although the interest elasticity estimates are not zero for both aggregates, as predicted by the quantity theory demand for money, they are quite low and statistically different than the implied value of the Baumol-Tobin transactions theory.

\section{Table 2 - Conventional Money Demand Functions}

\begin{tabular}{lcccccc} 
Explanatory & \multicolumn{3}{c}{ Standard } & & & RESET \\
Variable & Coefficient & error & $t$-statistic & $p$-value & $\bar{R}^{2}$ & $F$ \\
\hline
\end{tabular}

\section{M1}

$\begin{array}{lrrrrrr}\text { Constant } & -6.575 & 0.943 & -6.969 & 0.000 & 0.897 & 1.099 \\ \text { Ln R } & -0.108 & 0.037 & -2.899 & 0.006 & & \\ \text { Ln Y } & 1.012 & 0.040 & 25.240 & 0.000 & & \end{array}$

\section{M2}

\begin{tabular}{lrrrrrr} 
Constant & -6.615 & 0.787 & -8.396 & 0.000 & 0.940 & 0.110 \\
Ln R & -0.102 & 0.024 & -4.165 & 0.000 & & \\
Ln Y & 1.061 & 0.032 & 32.468 & 0.000 & & \\
\hline
\end{tabular}

Notes: The reported explanatory variables are all included in each of the regressions. The simple information set only includes the logarithm of short term interest rates and the logarithm of real GDP.

Table 3 presents the institution results for both money measures. The estimation procedure we opt for is to control sequentially for each institutional variable conditioned on the simple information set. The reasoning stems from issues regarding simultaneity and mutual 
exclusiveness. In particular, we are concerned with high correlations between the bureaucracy and corruption indexes and the small variance of the political indexes. As well, we are also apprehensive about the validity and consistency of OLS once multiple indexes measured by scale are included concurrently and when numerous degrees of freedom are lost from including multiple explanatory variables in our small sample. Although Kenny (1991) and Levine (2002) do not take the same approach, Beck and Levine (2004) do take a similar approach when investigating associations between stock market and bank development with economie growth. As a result, we are simply interested in the influential direction each of

Table 3 - Institutions, Political, Macro-stability, and Money Demand

Explanatory

Standard

RESET

Variable

Coefficient
error

$t$-statistic $p$-value

$\bar{R}^{2}$
F

M1

$\begin{array}{lrrrrrr}\text { Ln School80 } & -0.395 & 0.161 & -2.452 & 0.018 & 0.904 & 1.003 \\ \text { Ln BMP } & 0.095 & 0.136 & 0.698 & 0.489 & 0.895 & 1.027 \\ \text { Ln GOV } & -0.086 & 0.310 & -0.279 & 0.781 & 0.895 & 1.093 \\ \text { Ln Trade } & -0.422 & 0.309 & -1.363 & 0.180 & 0.902 & 0.289 \\ \text { Civil } & 0.034 & 0.058 & 0.593 & 0.556 & 0.895 & 1.205 \\ \text { REVC } & -0.257 & 0.219 & -1.174 & 0.247 & 0.896 & 1.105 \\ \text { ASSASS } & -0.081 & 0.128 & -0.632 & 0.530 & 0.895 & 0.892 \\ \text { Bureau } & -0.051 & 0.095 & -0.543 & 0.590 & 0.895 & 1.067 \\ \text { Corrupt } & -0.045 & 0.087 & -0.512 & 0.611 & 0.895 & 0.934\end{array}$

\begin{tabular}{lrrrrrr} 
Ln School80 & 0.056 & 0.132 & 0.424 & 0.673 & 0.939 & 0.107 \\
Ln BMP & -0.531 & 0.131 & -4.059 & 0.000 & 0.943 & 0.096 \\
Ln GOV & 0.274 & 0.183 & 1.490 & 0.143 & 0.941 & 0.151 \\
Ln Trade & -0.046 & 0.319 & -0.145 & 0.885 & 0.939 & 0.169 \\
Civil & 0.002 & 0.036 & 0.071 & 0.943 & 0.939 & 0.104 \\
REVC & -0.228 & 0.163 & -1.400 & 0.168 & 0.940 & 0.148 \\
ASSASS & -0.178 & 0.103 & -1.724 & 0.092 & 0.942 & 0.354 \\
Bureau & 0.028 & 0.068 & 0.416 & 0.679 & 0.939 & 0.090 \\
Corrupt & 0.061 & 0.054 & 1.130 & 0.264 & 0.940 & 0.020 \\
\hline
\end{tabular}

Notes: The reported explanatory variables are included one-by-one in each of the regressions. The simple information set only includes the log of the interest rate and the log of real GDP. 
the explanatory variables has on the money measures and caution on interpreting the results as exploitable elasticities.

The results in the top panel of Table 3 imply that only the educational variable is significantly related to money demand when considering a narrow measure. The sign of the coefficient also theoretically conforms because increases in the level of workforce education impact money demand negatively from a narrow perspective. This result is also consistent with Kenny (1991) where he also finds a negative relationship between literacy and M1. None of the other institutional indicators enter the narrow money demand regressions at the $10 \%$ level. With regards to the broader aggregate, Table 3 shows that the black market premium and assassination variables enter significantly. However, the sign of the black market premium coefficient is incorrect from the theoretical expectation. The negative sign on the assassination coefficient corresponds to our prediction that domestic turmoil would lead to a substitution out of money and into other tangible assets. However, given that it narrowly makes the $10 \%$ level we are still aware of potentially making a Type II error. None of the other institutional indicators enter the broad money demand regressions at the $10 \%$ level.

The implication of both the narrow and broad money regressions is that conditioning on institutions may not be so informative and unnecessary when investigating money demand issues. This follows from only one out of the nine institutional variables entering the narrow specification significantly and only two out of the nine being significant in the broad specification. As a result, it would be suspect to add any of the institutional variables to the conditioning information set. One interpretation may be that the demand for both aggregates could be stable irrespective of most institutional differences. In fact, in both specifications the elasticities with respect to income and the interest rate remain statistically similar to those in Table 2.

Table 4 presents the results when controlling for financial structure. The same estimation methods were used as in the institutional specification. Three of the structure measures enter the narrow specification significantly at the $10 \%$ level. In particular, the activity, size, and aggregate coefficients are all negative and of similar statistical magnitude, with size having the largest effect. The implication is that some measures of financial structure indicate that money demand is negatively related to market-based economies. This result corresponds to the economie theory outlined in the specification 
section. However, it also shows that there is some measurement sensitivity to such a conclusion. On the other hand, only the size variable is significant at the $10 \%$ level in the broad specification. This result suggests that measures of financial structure are for the most part statistically trivial when investigating money demand from a broad perspective. Again, the elasticities with respect to income and the interest rate remain statistically similar to those in Table 2.

\section{Table 4 - Financial Structure and Money Demand}

\begin{tabular}{|c|c|c|c|c|c|c|}
\hline $\begin{array}{l}\text { Explanatory } \\
\text { Variable }\end{array}$ & Coefficient & $\begin{array}{l}\text { Standard } \\
\text { error }\end{array}$ & $t$-statistic & $p$-value & $\bar{R}^{2}$ & $\begin{array}{c}\text { RESET } \\
F\end{array}$ \\
\hline
\end{tabular}

M1

$\begin{array}{lrrrrrr}\text { Structure-Activity } & -0.170 & 0.091 & -1.854 & 0.070 & 0.902 & 1.038 \\ \text { Structure-Size } & -0.204 & 0.107 & -1.900 & 0.064 & 0.901 & 1.920 \\ \text { Structure-Efficiency } & -0.110 & 0.094 & -1.168 & 0.249 & 0.899 & 1.157 \\ \text { Structure-Aggregate } & -0.194 & 0.105 & -1.839 & 0.073 & 0.903 & 1.377 \\ \text { Structure-Regulatory } & 0.014 & 0.031 & 0.461 & 0.647 & 0.895 & 0.929\end{array}$

M2

\begin{tabular}{lrrrrrr} 
Structure-Activity & -0.002 & 0.066 & -0.031 & 0.975 & 0.939 & 0.113 \\
Structure-Size & -0.132 & 0.070 & -1.872 & 0.068 & 0.942 & 0.117 \\
Structure-Efficiency & 0.071 & 0.075 & 0.951 & 0.347 & 0.941 & 0.064 \\
Structure-Aggregate & -0.009 & 0.074 & -0.121 & 0.904 & 0.939 & 0.116 \\
Structure-Regulatory & -0.002 & 0.027 & -0.108 & 0.914 & 0.939 & 0.102 \\
\hline
\end{tabular}

Notes: The reported explanatory variables are included one-by-one in each of the regressions. The simple information set only includes the log of the interest rate and the log of real GDP.

Table 5 presents the results when conditioning on the simple information set and controlling for financial development. The elasticities with respect to income and the interest rate again remain statistically similar to those in Table 2 for both aggregates. Using the same estimation method as the previous specification for financial structure, the results indicate that measures of financial development do not bring forth additional information regarding narrow money demand. None of the financial variables enter significantly at the $10 \%$ level. Conversely, in the broad specification there are intuitive results. All of the four measures of financial development enter significantly at the $10 \%$ level or higher. The sign on all of the coefficients is 
positive. Recall that the implied sign may be positive or negative. Given the consistent positive sign, we argue that this may suggest possible evidence that although greater financial development would bring forth additional services through financial arrangements, the benefits of such services may be outweighed by the costs and may actually raise transaction costs on a cross country scale. Kenny (1991) also finds a significantly positive estimate on the bank proximity variable in his M2 specification. Such results warrant further analysis before a definitive conclusion can be made.

\section{Table 5 - Financial Development and Money Demand}

\begin{tabular}{lrcrrrr}
$\begin{array}{l}\text { Explanatory } \\
\text { Variable }\end{array}$ & Coefficient & $\begin{array}{c}\text { Standard } \\
\text { error }\end{array}$ & $t$-statistic & $p$-value & $\bar{R}^{2}$ & $\begin{array}{c}\text { RESET } \\
\text { M1 } \\
\end{array}$ \\
& & & & & & \\
\hline & & & & & & \\
Finance-Activity & -0.044 & 0.073 & -0.609 & 0.545 & 0.896 & 0.946 \\
Finance-Size & 0.033 & 0.173 & 0.194 & 0.847 & 0.895 & 1.080 \\
Finance-Efficiency & -0.069 & 0.064 & -1.072 & 0.289 & 0.897 & 0.785 \\
Finance-Aggregate & -0.074 & 0.143 & -0.514 & 0.609 & 0.895 & 0.974
\end{tabular}

M2

\begin{tabular}{lllllll} 
Finance-Activity & 0.143 & 0.060 & 2.356 & 0.023 & 0.949 & 0.009 \\
Finance-Size & 0.447 & 0.127 & 3.522 & 0.001 & 0.952 & 0.089 \\
Finance-Efficiency & 0.110 & 0.057 & 1.917 & 0.062 & 0.944 & 0.022 \\
Finance-Aggregate & 0.304 & 0.113 & 2.679 & 0.010 & 0.950 & 0.006 \\
\hline
\end{tabular}

Notes: The reported explanatory variables are included one-by-one in each of the regressions. The simple information set only includes the log of the interest rates and the log of real GDP.

\section{Robustness}

So far, we have followed Kenny (1991), Levine (2002), and Beck and Levine (2004) and treated countries as homogeneous units using the same regression model for all countries in the sample. In this section we explore whether heterogeneity exists in our cross-country database, and in doing so, we provide an approach to overcome it. We use an automatic classification program (AutoClass) for cluster analysis, developed by researchers at the Ames Research Center - for a description of the AutoClass program, see Stutz and Cheeseman 
(1996) or Serletis (2005) for a recent application in the context of monetary aggregation. In general, classification analysis may be conducted by employing either a supervised or an unsupervised approach. Traditional cluster analysis is supervised; it creates predetermined classes and identifies membership on the basis of maximizing both in-class similarities and out-of-class differences - see, for example, Dillon and Goldstein (1984).

\subsection{Bayesian Classification Inference}

The classifications and cluster analysis preformed by AutoClass are sensitive to the choice of sorting characteristics chosen a priori. To overcome this potential pitfall, we conduct ten different sorts in order to build power, robust results, and to determine if heterogeneity exists among the 48 countries. Initially we paired real GDP per capita and the average price level over the 1980-1995 time period as the sorting characteristics. The rationale behind this sort is to determine whether a cluster can be formed based on economic development and inflation. In this case we define high inflation countries as those with average price levels, over the $1980-95$ period, which are far away from the 1995 base level. This sort grouped the data into two clusters based on the highest probability of class association. Table 6 presents the results with class 1 having 27 countries and class 2 having 21 countries. Furthermore, the probability of class membership for each of the 48 countries is quite pronounced by fluctuating from 0.814 to 1 .

We then proceeded by considering real GDP per capita (in U.S. dollars) along with schooling and each of Levine's (2002) financial structure and development variables. Although none of these nine sorts yielded the exact same classification as the initial pairing, they did come close. In particular, six of the financial structure and development sorts produced class associations consistent amongst each other and the schooling sort was also nearly the same as the price sort. However, the probability of class association was very weak in some cases. Specifically, Cyprus, Greece, Israel, Portugal and Taiwan frequently bounced between classes and had low probabilities of class association ranging from 0.532 to the low 0.7 's. Further inspection of the data revealed that these five countries consistently ranked either at the top echelon for one of the variables and at the bottom for the other variable in the pairing or persistently in the middle, which makes it difficult for AutoClass to distinguish them from either class.

Given the circumstances, we abandon the assumption that all the countries can be treated as a homogeneous unit and split the sample 


\begin{tabular}{ll} 
TABLE $6-$ Autoclass & Cluster Inference \\
Class 1 & Class 2 \\
\hline Argentina & Australia \\
Brazil & Austria \\
Chile & Belgium \\
Colombia & Canada \\
Ecuador & Cyprus \\
Egypt & Denmark \\
Ghana & Finland \\
Greece & France \\
Honduras & Germany \\
India & Ireland \\
Israel & Italy \\
Jamaica & Japan \\
Kenya & Netherlands \\
Malaysia & New Zealand \\
Mexico & Norway \\
Pakistan & Spain \\
Panama & Sweden \\
Peru & Switzerland \\
Philippines & Taiwan, China \\
Portugal & United Kingdom \\
South Africa & United States \\
Sri Lanka & \\
Thailand & \\
Trinidad and Tobago & \\
Tunisia & \\
Turkey & \\
Zimbabwe & \\
\hline & \\
\hline
\end{tabular}

into two sub-samples with each reflecting the three nearly identical classifications. Then for each sub-sample we estimate the money demand specifications outlined in the previous section to investigate whether the heterogenous specification results are sensitive to the five questionable countries. Estimation of the three different possible class structures generated nearly identical results. As a result, we use the high probability of class association in the price sort as a selection criteria and prefer using the cluster results in Table 6, which seem to fit the data quite well. This also allows us to loosely identify the sample treated by class 1 as 'developing, high-inflation countries' and the sample treated by class 2 as 'developed, low-inflation countries.'

However, we acknowledge that such labeling is contentious, especially for Greece, Israel and Portugal. Although each of these countries do have average or above average per capita real GDP in U.S. dollars and are also ranked in the upper end on the United Nation's 2004 Human Development Report, their corresponding price levels are far from the 1995 base level. It is for such reasons 
that we would then consider them as being at the very upper end of the 'developing, high-inflation countries.'. With regards to the 'developed low-inflation countries,' 19 of the 21 members represent the top 21 spots on the United Nations 2004 Human Development Index - Cyprus ranks 30 and Taiwan is not listed because it is grouped in with mainland China. The aim of such branding is to allow for heuristic inferences rather than corresponding to a precise taxonomy. This criteria is met by reflecting the Bayesian viewpoint that membership in one class differentiates membership in the other class through diversity in country characteristics.

\section{Table 7 - Conventional Money Demand}

\begin{tabular}{llccccc} 
Explanatory & \multicolumn{3}{c}{ Standard } & & RESET \\
Variable & Coefficient & error & $t$-statistic & $p$-value & $\bar{R}^{2}$ & $F$ \\
\hline
\end{tabular}

\section{M1}

Class 1 (Developing, high-inflation countries)

$\begin{array}{lrrrrrr}\text { Constant } & -5.818 & 1.041 & -5.586 & 0.000 & 0.913 & 0.182 \\ \text { Ln R } & -0.103 & 0.041 & -2.495 & 0.020 & & \\ \text { Ln Y } & 0.981 & 0.045 & 21.358 & 0.000 & & \end{array}$

Class 2 (Developed, low-inflation countries)

$\begin{array}{lrrrrrr}\text { Constant } & -7.673 & 2.432 & -3.153 & 0.005 & 0.792 & 0.447 \\ \text { Ln R } & -0.326 & 0.476 & -0.685 & 0.502 & & \\ \text { Ln Y } & 1.070 & 0.069 & 15.375 & 0.000 & & \end{array}$

Class 1 (Developing, high-inflation countries)

$\begin{array}{lrrrrrr}\text { Constant } & -7.749 & 1.169 & -6.628 & 0.000 & 0.940 & 0.500 \\ \text { Ln R } & -0.108 & 0.025 & -4.354 & 0.000 & & \\ \text { Ln Y } & 1.108 & 0.050 & 21.932 & 0.000 & & \end{array}$

Class 2 (Developed, low-inflation countries)

\begin{tabular}{lrrrrrr} 
Constant & -3.832 & 1.156 & -3.312 & 0.004 & 0.870 & 0.215 \\
Ln R & -0.523 & 0.300 & -1.742 & 0.098 & & \\
Ln Y & 0.991 & 0.044 & 22.340 & 0.000 & & \\
\hline
\end{tabular}

Notes: The reported explanatory variables are all included in each of the regressions. The simple information set only includes the log of the interest rate and the log of real GDP. 


\subsection{Cluster Results}

Table 7 presents the initial results for the conventional money demand specification for both classes and both monetary aggregates. When the narrow measure of money is considered, the estimated real income elasticity of the demand for real balances is highly significant for both the developing, high-inflation countries and developed, lowinflation countries. As before, we test if the coefficient is equal to one and cannot reject the hypothesis for either class. These results are again in accordance with the quantity theory demand for money. The estimated interest elasticity of the demand for real balances is almost identical to the result found in Table 2 for the developing, high-inflation class. However, for the developed, low-inflation class the coefficient is not significant at any conventional level. This finding also conforms with the quantity theory demand for money. When the simple information set is regressed on the broad monetary aggregate, the estimated real income elasticity of the demand for real balances is statistically different from one for the developing-high inflation class, but not for the developed, low-inflation class. The estimated interest elasticity of the demand for real balances remains stable and virtually unchanged for the developing, high-inflation class. Regarding the developed, low-inflation class, the estimated interest elasticity moves toward the Baumol-Tobin prediction but is barely significant at the $10 \%$ level. In comparison to the homogenous sample, the conventional demand for real balances seems to be relatively consistent and fairly stable under both sub-samples.

The institutional parameter estimates for the two classes are presented in Table 8A (for M1) and Table 8B (for M2). The schooling variable is highly significant for the developing, high-inflation class but not for the developed, low-inflation class. The estimated coefficient is also larger in magnitude than the previous estimate indicating that it may have previously been biased downwards. The assassination measure is also highly significant for the developing, high-inflation class but not the developed, low-inflation class. The sign of the coefficient is consistent with the prediction made earlier in the specification section. None of the other variables enter significantly in the developing, high-inflation sample. However, the black market premium, trade openness, and civil rights measures do significantly enter the developed, low-inflation sample. In particular, they all theoretically conform. A higher black market premium raises the cost of transacting and positively affects the demand for real balances. Additional exposure to the global trading system and decreases in freedom negatively impact the demand for real balances. 
In particular, these two findings may help shed some light into recent economic developments surrounding the United States, with regards to their large trade deficit and the debate surrounding the legislative passage of the Patriot Act. However, such analysis is beyond the scope of this paper.

In the broad specification, the estimated black market premium coefficient is significant for the developing, high-inflation class. The coefficient is of similar magnitude to the one estimated in the homogeneous sample and has the wrong sign again. The estimated government expenditure, trade openness, and assassination coefficients are also highly significant. The positive sign on the government

\section{Table 8A - Institutions, Political, Macro-stability and M1 Money Demand}

\begin{tabular}{lcccccc} 
Explanatory & \multicolumn{3}{c}{ Standard } & & \multicolumn{2}{c}{ RESET } \\
Variable & Coefficient & error & $t$-statistic & $p$-value & $\bar{R}^{2}$ & $F$ \\
\hline
\end{tabular}

Class 1 (Developing, high-inflation countries)

$\begin{array}{lrrrrrr}\text { Ln School80 } & -0.504 & 0.139 & -3.609 & 0.001 & 0.937 & 2.461 \\ \text { Ln BMP } & -0.039 & 0.154 & -0.257 & 0.799 & 0.909 & 0.150 \\ \text { Ln GOV } & 0.268 & 0.357 & 0.751 & 0.460 & 0.913 & 0.035 \\ \text { Ln Trade } & 0.037 & 0.219 & 0.172 & 0.864 & 0.909 & 0.153 \\ \text { Civil } & 0.072 & 0.053 & 1.363 & 0.186 & 0.916 & 0.016 \\ \text { REVC } & -0.192 & 0.153 & -1.252 & 0.223 & 0.911 & 0.378 \\ \text { ASSASS } & -0.252 & 0.099 & -2.536 & 0.018 & 0.923 & 0.858 \\ \text { Bureau } & 0.109 & 0.083 & 1.311 & 0.203 & 0.914 & 0.419 \\ \text { Corrupt } & 0.033 & 0.118 & 0.279 & 0.782 & 0.909 & 0.143\end{array}$

Class 2 (Developed, low-inflation countries)

\begin{tabular}{lrrrrrr} 
Ln School80 & -0.684 & 0.563 & -1.213 & 0.241 & 0.788 & 0.594 \\
Ln BMP & 19.114 & 9.278 & 2.059 & 0.055 & 0.791 & 0.072 \\
Ln GOV & -0.878 & 0.984 & -0.892 & 0.384 & 0.789 & 0.414 \\
Ln Trade & -1.173 & 0.616 & -1.902 & 0.074 & 0.832 & 0.858 \\
Civil & -0.166 & 0.089 & -1.855 & 0.081 & 0.786 & 0.306 \\
REVC & -2.188 & 1.646 & -1.329 & 0.201 & 0.795 & 0.487 \\
ASSASS & 0.547 & 0.371 & 1.473 & 0.159 & 0.791 & 0.386 \\
Bureau & -0.357 & 0.285 & -1.249 & 0.228 & 0.796 & 0.294 \\
Corrupt & -0.080 & 0.236 & -0.337 & 0.740 & 0.781 & 0.386 \\
\hline
\end{tabular}

Notes: The reported explanatory variables are included one-by-one in each of the regressions. The simple information set only includes the logarithm of short term interest rates and the logarithm of real GDP in USA dollars. 
Table 8в - Institutions, Political, Macro-stability and M2 Money Demand

Explanatory

Standard

RESET

Variable

Coefficient

error

$t$-statistic $p$-value $\quad \bar{R}^{2}$

$F$

Class 1 (Developing, high-inflation countries)

$\begin{array}{lrrrrrr}\text { Ln School80 } & 0.078 & 0.172 & 0.456 & 0.652 & 0.938 & 0.384 \\ \text { Ln BMP } & -0.503 & 0.125 & -4.024 & 0.001 & 0.948 & 0.001 \\ \text { Ln GOV } & 0.696 & 0.182 & 3.813 & 0.001 & 0.957 & 0.019 \\ \text { Ln Trade } & 0.505 & 0.178 & 2.831 & 0.009 & 0.954 & 0.028 \\ \text { Civil } & 0.013 & 0.043 & 0.318 & 0.753 & 0.938 & 0.398 \\ \text { REVC } & -0.226 & 0.133 & -1.696 & 0.103 & 0.940 & 1.186 \\ \text { ASSASS } & -0.309 & 0.092 & -3.329 & 0.003 & 0.954 & 2.149 \\ \text { Bureau } & 0.095 & 0.080 & 1.191 & 0.245 & 0.941 & 0.559 \\ \text { Corrupt } & 0.129 & 0.087 & 1.474 & 0.154 & 0.943 & 0.214\end{array}$

Class 2 (Developed, low-inflation countries)

\begin{tabular}{lrrrrrl} 
Ln School80 & -0.092 & 0.279 & -0.331 & 0.744 & 0.863 & 0.212 \\
Ln BMP & 11.429 & 7.480 & 1.527 & 0.145 & 0.867 & 0.019 \\
Ln GOV & -0.152 & 0.651 & -0.234 & 0.817 & 0.863 & 0.212 \\
Ln Trade & -1.141 & 0.559 & -2.040 & 0.057 & 0.924 & 4.581 \\
Civil & -0.033 & 0.060 & -0.554 & 0.587 & 0.863 & 0.181 \\
REVC & 0.093 & 0.968 & 0.096 & 0.924 & 0.862 & 0.199 \\
ASSASS & 0.370 & 0.219 & 1.690 & 0.109 & 0.869 & 0.166 \\
Bureau & -0.189 & 0.165 & -1.146 & 0.267 & 0.868 & 0.108 \\
Corrupt & -0.007 & 0.086 & -0.087 & 0.931 & 0.862 & 0.227 \\
\hline
\end{tabular}

Notes: The reported explanatory variables are included one-by-one in each of the regressions. The simple information set only includes the logarithm of short term interest rates and the logarithm of real GDP in USA dollars.

expenditure estimate implies that public and private spending are complements. This seems reasonable given that developing countries expend large amounts on infrastructure and capital projects. We also test if the government expenditure coefficient is equal to one and weakly accept the null hypothesis of private spending and public spending being perfect complements. However, the estimated trade coefficient does not follow the prediction previously made, given that it is positive. An increase in the number of assassinations decreases the demand for real money balances as predicted. Regarding the developed-low inflation sample, only the trade openness coefficient 
enters significantly. It is again negative, as in the narrow regression and of similar magnitude.

For both monetary aggregates, the institutional results clearly display some degree of heterogeneity with regards to institutional effects between the developed, low-inflation countries and the developing, high-inflation countries. The estimated real income and interest elasticities remain similar to those in Table 7 for the developing, high-inflation cluster. Regarding the developed, low-

\section{TABle 9 - Financial Structure and Money Demand}

\begin{tabular}{lcccccc} 
Explanatory & \multicolumn{7}{c}{ Standard } \\
Variable & Coefficient & error & $t$-statistic & $p$-value & $\bar{R}^{2}$ & RESET $F$ \\
\hline \multicolumn{7}{c}{ M1 } \\
& Class 1 (Developing, high-inflation countries) \\
Structure-Activity & -0.129 & 0.112 & -1.151 & 0.262 & 0.919 & 0.141 \\
Structure-Size & -0.070 & 0.112 & -0.624 & 0.538 & 0.911 & 0.031 \\
Structure-Efficiency & -0.124 & 0.096 & -1.289 & 0.210 & 0.920 & 0.114 \\
Structure-Aggregate & -0.131 & 0.122 & -1.068 & 0.296 & 0.918 & 0.089 \\
Structure-Regulatory & 0.040 & 0.043 & 0.926 & 0.364 & 0.912 & 0.520 \\
& Class $2($ Developed, low-inflation countries) & & \\
Structure-Activity & -0.221 & 0.161 & -1.367 & 0.189 & 0.794 & 0.288 \\
Structure-Size & -0.485 & 0.262 & -1.851 & 0.082 & 0.814 & 0.925 \\
Structure-Efficiency & -0.112 & 0.197 & -0.571 & 0.575 & 0.784 & 0.274 \\
Structure-Aggregate & -0.314 & 0.197 & -1.597 & 0.129 & 0.800 & 0.306 \\
Structure-Regulatory & -0.027 & 0.071 & -0.382 & 0.706 & 0.781 & 0.654
\end{tabular}

M2

Class 1 (Developing, high-inflation countries)

$\begin{array}{lrrrrrr}\text { Structure-Activity } & -0.060 & 0.084 & -0.717 & 0.480 & 0.939 & 0.275 \\ \text { Structure-Size } & -0.143 & 0.074 & -1.934 & 0.065 & 0.944 & 0.171 \\ \text { Structure-Efficiency } & 0.005 & 0.089 & 0.058 & 0.954 & 0.938 & 0.525 \\ \text { Structure-Aggregate } & -0.069 & 0.091 & -0.762 & 0.453 & 0.940 & 0.255 \\ \text { Structure-Regulatory } & 0.032 & 0.041 & 0.774 & 0.446 & 0.939 & 0.599\end{array}$

Class 2 (Developed, low-inflation countries)

\begin{tabular}{lrrrrrr} 
Structure-Activity & 0.041 & 0.124 & 0.334 & 0.742 & 0.863 & 0.289 \\
Structure-Size & -0.089 & 0.148 & -0.604 & 0.554 & 0.864 & 0.233 \\
Structure-Efficiency & 0.126 & 0.148 & 0.851 & 0.406 & 0.869 & 0.653 \\
Structure-Aggregate & 0.053 & 0.131 & 0.411 & 0.686 & 0.863 & 0.271 \\
Structure-Regulatory & -0.017 & 0.049 & -0.363 & 0.721 & 0.863 & 0.321 \\
\hline
\end{tabular}

Notes: The reported explanatory variables are included one-by-one in each of the regressions. The simple information set only includes the logarithm of short term interest rates and the logarithm of real GDP. 
inflation sample, the real income and interest elasticities also remain similar to those presented in Table 7, when we consider M1 as the dependent variable. But, when we consider the broad aggregate, the high interest elasticity in Table 7 does become highly significant for some cases and is of similar magnitude. Therefore, we conclude that the interest elasticity of M2 in developed, low-inflation countries is likely to be statistically different than the interest elasticity found in the developing, high-inflation cluster. We attribute the small sample of 21 observations and lack of degrees of freedom to be the source of bias in the conventional money demand estimation. The real income elasticity does however remain stable in the M2 specification.

The financial structure estimates are reported in Table 9. With respect to the narrow aggregate, none of the financial structure measures enter the developing-high inflation class significantly at conventional levels. Only the size measure enters significantly at the $10 \%$ level for the developed, low-inflation sample. In the M2 specification, only the size measure enters significantly at the $10 \%$ level for the developing, high-inflation sample. None of the financial structure measures are significant for the developed, low-inflation class. In the cross-country results, size is also significant for both M1 and M2 and of similar magnitude to the coefficients estimated in each of the cluster sub-samples. Since only one of the five measures is consistent within both the cross-country and cluster regressions, we interpret that the demand for real balances is relatively stable irrespective of structural financing. The real income elasticity and the interest elasticity of the demand for real balances remain similar to what we discussed in the previous paragraph for both classes.

Table 10 presents the financial development parameter estimates for the two classes. Not one of the four measures enter the narrow specification for either class significantly. This result was also found in the cross country results. When we treat M2 as the dependent variable, all four measures of financial development are highly significant for the developing, high-inflation class. The estimated coefficients are positive and of similar statistical magnitude to those in Table 4 . When we consider the developed, low-inflation countries in the broad specification, none of the four measures of financial development enter significantly. Given the results in Table 9, we conclude that the developing, high-inflation countries are driving the cross-country results in Table 4. In particular, the persistent positive sign on all of the measures, allows us to infer that the benefits brought forth by financial services in developing, highinflation countries are outweighed by the costs of utilizing them and 
actually raise transaction costs. One explanation could be that in the early stages of financial development economies of scale have not yet been captured to bring transaction costs down, or to a constant state where money demand would not be affected, as it appears in the developed, low-inflation class. The real income elasticity and the interest elasticity of the demand for real balances remain similar to what was discussed in the prior paragraphs.

\section{Table 10 - Financial Development and Money Demand}

\begin{tabular}{lcccccc} 
Explanatory & \multicolumn{3}{c}{ Standard } & & RESET \\
Variable & Coefficient & error & $t$-statistic & $p$-value & $\bar{R}^{2}$ & $F$ \\
\hline
\end{tabular}

\begin{tabular}{lrrrrrr}
\multicolumn{7}{c}{ Class 1 (Developing, high-inflation countries) } \\
Finance-Activity & -0.030 & 0.066 & -0.455 & 0.653 & 0.910 & 0.155 \\
Finance-Size & 0.097 & 0.140 & 0.692 & 0.495 & 0.911 & 0.101 \\
Finance-Efficiency & -0.018 & 0.079 & -0.228 & 0.821 & 0.909 & 0.170 \\
Finance-Aggregate & 0.007 & 0.134 & 0.005 & 0.996 & 0.909 & 0.175
\end{tabular}

Class 2 (Developed, low-inflation countries)

$\begin{array}{lllllll}\text { Finance-Activity } & -0.063 & 0.236 & -0.266 & 0.793 & 0.781 & 0.334 \\ \text { Finance-Size } & -0.085 & 1.080 & -0.079 & 0.938 & 0.780 & 0.417 \\ \text { Finance-Efficiency } & -0.097 & 0.135 & -0.720 & 0.481 & 0.785 & 0.312 \\ \text { Finance-Aggregate } & -0.172 & 0.465 & -0.370 & 0.716 & 0.783 & 0.327\end{array}$

M2

Class 1 (Developing, high-inflation countries)

$\begin{array}{lllllll}\text { Finance-Activity } & 0.133 & 0.065 & 2.056 & 0.051 & 0.953 & 0.557 \\ \text { Finance-Size } & 0.370 & 0.128 & 2.892 & 0.008 & 0.957 & 0.661 \\ \text { Finance-Efficiency } & 0.160 & 0.067 & 2.384 & 0.026 & 0.952 & 0.562 \\ \text { Finance-Aggregate } & 0.313 & 0.118 & 2.648 & 0.014 & 0.957 & 0.628\end{array}$

Class 2 (Developed, low-inflation countries)

\begin{tabular}{lllllll} 
Finance-Activity & 0.163 & 0.189 & 0.863 & 0.400 & 0.876 & 1.070 \\
Finance-Size & 1.022 & 0.724 & 1.410 & 0.176 & 0.896 & 0.590 \\
Finance-Efficiency & 0.049 & 0.107 & 0.459 & 0.652 & 0.864 & 0.375 \\
Finance-Aggregate & 0.311 & 0.369 & 0.844 & 0.410 & 0.874 & 0.828 \\
\hline
\end{tabular}

Notes: The reported explanatory variables are included one-by-one in each of the regressions. The simple information set only includes the logarithm of short term interest rates and the logarithm of real GDP. 


\section{Conclusion}

We have used cross-country data (for 48 countries over the 19801995 period) to investigate the long-run relationship between both narrow and broad monetary aggregates and interest rates, real GDP, institutions, financial structure and financial development. We have shown that the interest and income elasticities of real balances are fairly stable and conform to the theoretical prediction of the quantity theory demand for money. As well, we have found that institutions, financial structure, and development do play a role in the demand for money in an aggregate setting; albeit a limited role.

However, we have shown that the assumption that all of the countries can be treated as a homogeneous unit can cause systematic distortions. Specifically, we utilized unsupervised Bayesian methods based on finite mixture models and mathematical properties, to cluster the data set into two distinct groups. Regressions based on each of the partitioned data sets displayed heterogeneity with respect to the influence institutions, financial structure, and financial development have on money demand, for each of the two groups. We found that our developing, high-inflation class somewhat dominated the data set and distorted some of the developed, low-inflation class results. In particular, the role that the supplementary variables have in the money demand function depends not only on the specified aggregate, but also on the countries specified in the sample.

Apostolos Serletis

University of Calgary, Department of Economics, Calgary, Alberta, Canada

JASON VACCARO

University of Calgary, Department of Economics, Calgary, Alberta, Canada 


\section{R E F E R E N C E S}

Allen, F. and D. Gale (1999), Comparing Financial Systems, MIT Press: Cambridge, MA.

Barro, R.J. (1997), Macroeconomics (5th edition), MIT Press: Cambridge, MA.

Baumol, W.J. (1952), "The Transactions Demand for Cash: An Inventory Theoretic Approach”, Quarterly Fournal of Economics, 66: 545-556.

Beck, T. and R. Levine (2004), "Stock Markets, Banks and Growth: Panel Evidence”, Fournal of Banking and Finance, 28: 423-442.

Bhide, A. (1993), “The Hidden Costs of Stock Market Liquidity”, Fournal of Financial Intermediation, 34: 1-51.

Boot, A. and A.V. Thakor (1997), "Financial System Architecture", Review of Financial Studies, 10: 693-733.

Dillon, W.R. and M. Goldstein (1984), Multivariate Analysis, John Wiley \& Sons, Inc.

Engle, R.F. and C.W.J. Granger (1987), "Co-Integration and Error Correction: Representation, Estimation and Testing”, Econometrica, 55: 251-76.

Fischer, A. (2005), "Measuring Income Elasticity for Swiss Money Demand: What Do the Cantons Say About Financial Innovation?", Working Paper 05.01, Swiss National Bank.

Friedman, B.M. and K.N. Kuttner (1992), "Money, Income, Prices, and Interest Rates", American Economic Review, 82: 472-92.

Fujiki, H. and C.B. Mulligan (1996), "A Structural Analysis of Money Demand: CrossSectional Evidente from Japan”, Monetary and Economic Studies, 14: $53-78$.

Goldfeld, S.M. and D.E. Sichel (1990), The Demand for Money, In: Friedman B.M., Hahn F.H. (Eds), Handbook of Monetary Economics, vol. 1, NorthHolland: Amsterdam, 299- 356.

Hoffman, D.L. and R.H. Rasche (1996), Aggregate Money Demand Functions, Kluwer Academic Publishers.

Kenny, L.W. (1991), "Cross-Country Estimates of the Demand for Money and its Components”, Economic Inquiry, 29: 696-705.

Levine, R. (1997), "Financial Development and Economie Growth: Views and Agenda", Fournal of Economic Literature, 35: 688-726.

Levine, R. (2002), "Bank-Based or Market-Based Financial Systems: Which is Better?”, Fournal of Financial Intermediation, 11: 398-428.

Mulligan, C.B. and X. Sala-i-Martin (1992), "U.S Money Demand: Surprising Cross-Sectional Estimates", Brookings Papers on Economic Activity, 2: 285343.

Serletis, A. (2001), The Demand for Money: Theoretical and Empirical Approaches, Kluwer Academic: Norwell, MA. 
Serletis, A. (2005), "A Bayesian Classification Approach to Monetary Aggregation," Mimeo, Department of Economics, University of Calgary.

Sriram, S. (1999), "Survey of Literature on Demand for Money: Theoretical and Empirical Work with Special Reference to Error-Correction Models", Working Paper 64, International Monetary Fund.

Stutz, J. and P. Cheeseman (1996), AutoClass: A Bayesian Approach to Classification, In: Skilling J., Sibisi S. (Eds), Maximum Entropy and Bayesian Methods, Kluwer Academic.

Tobin, J. (1956), “The Interest-Elasticity of Transactions Demand for Cash", Review of Economics and Statistics, 38: 241-247.

United Nations (2004), Human Development Report (http://hdr.undp.org/ reports/global/2004).

\begin{abstract}
In this article we examine money demand issues using cross-country data, for 48 countries over the 1980-1995 period. In particular, we investigate conventional money demand functions, for both narrow and broad aggregates, and the role that institutions, financial structure and financial development may have in the demand for money. On the basis of possible heterogeneity within the cross-country data set, we exploit Bayesian classification and finite mixture models to partition the data based on statistical similarities and multi-dimensional structures. A re-examination of our initial regression results indicates that a great deal of heterogeneity exists between different groups of countries.
\end{abstract}

Keywords: Cross-country estimates; Bayesian classification;

JEL classification: C21; E41; E50

\title{
RIASSUNTO
}

\section{Evidenze internazionali sulla domanda di moneta}

Nel modello esaminiamo la domanda di moneta utilizzando dati cross section per 48 paesi, nel periodo compreso tra il 1980 e il 1995. In particolare, investighiamo le funzioni di domanda di moneta di tipo tradizionale, sia per stretti che per ampi aggregati, e il ruolo che le istituzioni, la struttura finanziaria e lo sviluppo finanziario possono giocare nella domanda di moneta. In considerazione di una possibile eterogeneità nella base dati dei diversi paesi, sfruttiamo la classificazione Bayesiana e i "finite mixture models" per suddividere i dati a seconda delle similitudini statistiche e delle strutture multidimensionali. Un riesame dei risultati della nostra regressione iniziale indica che esiste molta eterogeneità tra diversi gruppi di paesi. 